\title{
Keanekaragaman, aktivitas kunjungan, dan keefektifan lebah penyerbuk pada tanaman tomat (Solanum lycopersicum L: Solanaceae)
}

\author{
Diversity, foraging activity, and effectiveness of bee pollinators in \\ tomato plants (Solanum lycopersicum L: Solanaceae)
}

\author{
Andi Gita Maulidyah Indraswari ${ }^{{ }^{*}}$, Tri Atmowidi ${ }^{1}$, Sih Kahono ${ }^{2}$ \\ ${ }^{1}$ Departemen Biologi, Fakultas Matematika dan Ilmu Penetahuan Alam, Institut Pertanian Bogor \\ Jalan Agatis, Kampus IPB Dramaga, Bogor 16680 \\ ${ }^{2}$ Laboratorium Ekologi, Museum Zoologicum Bogoriense, Pusat Penelitian Biologi, \\ Lembaga Ilmu Pengetahuan Indonesia \\ Jalan Raya Jakarta Bogor KM 46, Cibinong, Bogor 16911
}

(diterima Juli 2015, disetujui Februari 2016)

\begin{abstract}
ABSTRAK
Tomat (Solanum lycopersicum L.) merupakan tanaman hermaprodit yang mampu melakukan penyerbukan sendiri. Walaupun demikian, tanaman tomat memerlukan polinator untuk lebih mengefektifkan proses penyerbukan. Penelitian ini bertujuan untuk mempelajari keanekaragaman, perilaku kunjungan, dan keefektifan lebah penyerbuk dalam pembentukan buah tomat. Keanekaragaman lebah penyerbuk diamati dengan metode scan sampling, sedangkan perilaku kunjungan lebah diamati dengan metode focal sampling. Dalam penelitian ini digunakan pertanaman yang dikurung dengan kain kasa dan pertanaman terbuka untuk membandingkan buah hasil penyerbukan dengan dan tanpa lebah. Hasil penelitian menunjukkan terdapat sebelas spesies lebah sebagai penyerbuk tomat, yaitu Megachile conjuncta Smith, Megachile fulfifrons Smith, Megachile unbripennis Smith, Xylocopa confusa Latreille, Xylocopa latipes Drury, Xylocopa caerulea Fabricius, Ceratina cognate Latreille, Nomia quadridentata Bingham, Amegilla cyrtandrae Lieftinck, Amegilla burneensis Friese, dan Apis cerana Fabricius. Tiga spesies lebah ditemukan dominan, yaitu $X$. confusa, $A$. cyrtandrae dan $C$. cognata. Lebah $X$. confusa mengunjungi bunga paling banyak, diikuti A. cyrtandrae, dan C. cognata. Total kunjungan pada tanaman paling lama terjadi pada C. cognata, diikuti $X$. confusa dan $A$. cyrtandrae. Penyerbukan oleh lebah meningkatkan $8,92 \%$ bunga yang berhasil menjadi buah, $43 \%$ panjang buah, $189 \%$ jumlah biji/buah, dan $355 \%$ bobot biji/buah tanaman tomat.
\end{abstract}

Kata kunci: efek penyerbukan, lebah penyerbuk, produksi buah, tomat (Solanum lycopersicum)

\begin{abstract}
Tomato (Solanum lycopersicum L.) is a hermaphrodite plant and capable of auto pollination. However it still need pollinators to maximize pollination success. This research was aimed to determine the diversity, foraging activity of pollinator bees and its effectiveness on seeds and fruits formation of tomato. Scan sampling method was used to determine the diversity of pollinators and focal sampling method was used to observe visiting behavior of the bees. We conducted two experiments i.e., screen caged plants and open plants to compare the effect of the bee pollinators on fruits and seeds set formation. Results showed that eleven species of bees were found, i.e., Megachile conjuncta Smith, Megachile fulfifrons Smith, Megachile unbripennis Smith, Xylocopa confusa Latreille, Xylocopa latipes Drury, Xylocopa caerulea Fabricius, Ceratina cognata Latreille, Nomia quadridentata Bingham, Amegilla cyrtandrae Lieftinck, Amegilla burneensis Friese, and
\end{abstract}

\footnotetext{
*Penulis korespondensi: Andi Gita Maulidyah Indraswari. Departemen Biologi, Fakultas Matematika dan Ilmu Pengetahuan Alam, Institut Pertanian Bogor, Kampus IPB Dramaga, Bogor 16680, Tel: 082349739688, Email: gitamaulidyah@gmail.com.
} 
Apis cerana Fabricius. Three species of bees were dominant, i.e., X. confusa, A. cyrtandrae, and C. cognata. Bee, $X$. confusa visited more flowers per minute, followed by $A$. cyrtandrae and $C$. cognata. The longest species visiting in plants were C. cognata, followed by $X$. confusa and A. cyrtandrae. Bee pollinators increase $8.92 \%$ of fruiting, $43 \%$ of fruit size, $189 \%$ of number of seeds per fruit, and $355 \%$ of weight of seeds of tomato plants.

Key words: bee pollinators, pollination effect, tomato (Solanum lycopersicum)

\section{PENDAHULUAN}

Tanaman tomat (Solanum lycopersicum L.) memiliki bunga hermaprodit yang dapat melakukan autogami. Bunga tomat memiliki tabung anter dengan celah kecil pada apikal yang membatasi akses serangga terhadap serbuk sari. Beberapa spesies lebah telah teradaptasi terhadap struktur bunga tomat tersebut dengan menggetarkan stamen (buzz pollination) sehingga kepala sari melepaskan polen dan jatuh di kepala putik (Silva et al. 2013). Beberapa spesies yang potensial sebagai penyerbuk tanaman tomat adalah Amegilla holmesi Rayment (Bell et al. 2006), Amegilla chlorocyanea Cockerell (Hogendoorn et al. 2007), Melipona quadrifasciata Peletier (Santos et al. 2009), Xylocopa sp., Hylaeus sp. Fabricius (Fajarwati et al. 2009), Bombus morio Swederus, Exomalopsis analis Spinola, Epicharis sp. (Neto et al. 2013), dan Bombus impatiens Cresson (Silva et al. 2013).

Beberapa penelitian melaporkan bahwa aktivitas kunjungan lebah bervariasi pada berbagai spesies tanaman. Lebah Xylocopa olivacea Fabricius mengunjungi 28 bunga/menit pada bunga Phaseolus vulgaris (Kingha et al. 2012), Apis mellifera Linnaeus mengunjungi 11,48 bunga/ menit dan Trigona laeviceps Smith mengunjungi 3,67 bunga/menit pada bunga Brasssica juncea (Kunjwal et al. 2014). Aktivitas kunjungan lebah pada bunga dipengaruhi oleh warna bunga, ketersediaan nektar dan polen, dan kesesuaian karakter bunga dengan tubuh lebah (Rianti et al. 2010). Penyerbukan oleh lebah memberikan kontribusi terhadap produksi buah, yaitu $41 \%$ pada cranberry, $7 \%$ pada blueberry, $26 \%$ pada tomat, $45 \%$ pada strawberry, dan $22-24 \%$ pada kapas (Delaplane \& Mayer 2000), termasuk estimasi nilai ekonomi mencapai US\$ 14.564.000 (Morse \& Calderone 2000; Mburu et al. 2006). Tanaman tomat yang dibantu penyerbukannya oleh lebah terjadi peningkatan ukuran buah dan jumlah biji per buah dibandingkan dengan penyerbukan sendiri atau tanpa bantuan serangga (Neto et al.
2013; Depra et al. 2014). Penelitian ini bertujuan untuk mempelajari keanekaragaman dan aktivitas kunjungan lebah penyerbuk serta keefektifannya dalam pembentukan buah tomat.

\section{BAHAN DAN METODE}

\section{Waktu dan lokasi penelitian}

Penelitian dilakukan pada bulan AgustusNovember 2014 di Lahan Pertanian Organik Bina Sarana Bakti, Kecamatan Cisarua, Bogor, Jawa Barat ( $\left.06^{\circ} 41,362^{\prime} \mathrm{LS}, 106^{\circ} 56.932 \mathrm{BT}^{\prime}\right)$, dengan ketinggian 953,9 $\mathrm{m}$ dpl.

\section{Pengamatan keanekaragaman lebah penyerbuk}

Keanekaragaman lebah penyerbuk diamati selama 25 hari pada 250 tanaman tomat yang sedang berbunga dengan metode scan sampling (Martin \& Bateson 1986). Pengamatan keanekaragaman lebah dilakukan pada tiga periode waktu, yaitu pukul 07:00-09:00, 09:00-11:00, dan 13:00-16:00 WIB pada saat cuaca cerah atau tidak hujan. Jumlah spesies dan individu lebah yang mengunjungi bunga tomat dicatat. Selama pengamatan keanekaragaman lebah, diukur parameter lingkungan, yaitu kelembaban, suhu udara, kecepatan angin, dan intensitas cahaya, yang dilakukan pada pukul 07:00, 09:00, 11:00, 13:00, dan 14:00 WIB. Parameter lingkungan diukur untuk melihat hubungan antara kondisi lingkungan dengan jumlah spesies dan individu lebah yang mengunjungi bunga tomat.

\section{Koleksi, preservasi, dan identifikasi spesimen}

Beberapa individu lebah penyerbuk yang mengunjungi bunga tomat dikoleksi dengan jaring serangga dan diawetkan secara kering (Triplehorn \& Johnson 2005). Spesimen lebah ditusuk menggunakan jarum serangga, selanjutnya dimasukkan dalam oven pada suhu $35^{\circ} \mathrm{C}$ selama tujuh hari. Spesimen dikeluarkan dari oven dan diberi label, kemudian dimasukkan ke dalam kotak 
dan disimpan dalam lemari pendingin selama tujuh hari pada suhu $-40{ }^{\circ} \mathrm{C}$. Identifikasi spesimen dilakukan sampai spesies berdasarkan Hurd \& Moure (1963) dan Michener (2007). Verifikasi spesimen dilakukan berdasarkan spesimen koleksi di Museum Zoologicum Bogoriense-LIPI, Cibinong, Bogor.

\section{Pengamatan aktivitas kunjungan lebah penyerbuk}

Aktivitas kunjungan lebah pada bunga tomat diamati selama 25 hari dengan metode focal sampling (Martin \& Bateson 1986). Aktivitas kunjungan diamati pada tiga spesies lebah, yaitu Xylocopa confusa Latreille, Amegilla cyrtandrae Lieftinck, dan Ceratina cognata Latreille, yang merupakan spesies dominan. Aktivitas kunjungan yang diamati adalah jumlah bunga yang dikunjungi per menit (foraging rate), lama kunjungan per bunga (flower handling time), dan lama kunjungan pada pertanaman (Dafni 1992).

\section{Pengukuran pollen load}

Pengukuran pollen load dilakukan untuk mengetahui jumlah polen yang menempel pada tubuh lebah setelah mengunjungi bunga tomat. Pengukuran pollen load dilakukan pada lebah $X$. confusa, A. cyrtandare, dan C. cognata. Satu individu lebah dimasukkan ke dalam tabung mikro berisi etanol dan gliserol dengan perbandingan 4 : 1 sebanyak $0,5 \mathrm{ml}$, kemudian dirotator selama 24 jam. Lebah kemudian dikeluarkan dari tabung dan cairan di sentrifugasi selama 10 menit dengan kecepatan $700 \mathrm{rpm}$. Sebanyak $0,1 \mathrm{ml}$ cairan tersebut diambil menggunakan pipet dan diletakkan pada Haemositometer, kemudian diamati di bawah mikroskop. Pengukuran pollen load dilakukan 10 kali untuk setiap spesies lebah (Dafni 1992).

\section{Pengukuran keefektifan lebah penyerbuk}

Pengukuran keefektifan lebah penyerbuk dilakukan pada tanaman bunga secara menyeluruh. Sebanyak 250 tanaman tomat dibiarkan terbuka sehingga lebah dapat mengunjungi bunga dan 250 tanaman tomat lainnya dikurung dengan kain kasa, untuk mencegah lebah mengunjungi bunga. Efektivitas lebah dalam penyerbukan tanaman tomat diukur dari persentase jumlah buah yang terbentuk (\%), ukuran buah (cm), jumlah biji, dan bobot biji per buah (g), yang dilakukan pada masing-masing 20 buah tanaman tomat yang terbuka dan dikurung kain kasa. Kadar karbohidrat, protein, dan vitamin $\mathrm{C}$ juga diukur pada masingmasing satu buah tomat tanpa kurungan dan yang dikurung kain kasa.

\section{Analisis data}

Diversitas dan kelimpahan lebah penyerbuk dianalisis menggunakan indeks Shannon (H'), kemerataan (E), dan kesamaan Sorensen (Cs) (Magurran \& McGill 2011).

Kaitan antara keanekaragaman lebah penyerbuk dengan periode waktu pengamatan, dan parameter lingkungan dianalisis dengan Principal Component Analysis (PCA) dan korelasi Pearson. Aktivitas kunjungan tiga spesies lebah penyerbuk dianalisis dengan ANOVA, dilanjutkan uji Tukey dengan selang kepercayaan 95\% menggunakan perangkat lunak SPSS 16.0. Perbandingan antara buah hasil penyerbukan lebah dan tanpa penyerbukan (dalam kurungan kasa) dianalisis dengan ANOVA, menggunakan perangkat lunak SPSS 16.0 (Duwi 2010).

\section{HASIL}

\section{Keanekaragaman lebah penyerbuk pada bunga tomat}

Serangga penyerbuk yang diamati pada tanaman tomat terdiri atas 11 spesies, yaitu Megachile conjuncta Smith, Megachile fulfifrons Smith, Megachile unbripennis Smith, X. confusa, Xylocopa latipes Drury, Xylocopa caerulea Fabricius, C. cognata, Nomia quadridentata Bingham, A. cyrtandrae, Amegilla burneensis Friese, dan Apis cerana Fabricius. Tiga spesies lebah penyerbuk ditemukan dengan kelimpahan tinggi, yaitu $X$. confusa (457 individu), $A$. cyrtandrae (227 individu), dan C. cognata (132 individu) (Tabel 1). Kesamaan lebah pengunjung antar periode waktu berkisar $84-94 \%$ dan kesamaan tertinggi terjadi pada siang-sore hari (94\%) (Gambar 1). Berdasarkan analisis PCA dan korelasi Pearson, kecepatan angin dan kelembaban udara cenderung berkorelasi negatif, sedangkan intensitas cahaya cenderung berkorelasi positif terhadap jumlah spesies dan individu serangga (Gambar 2), walaupun secara statistik tidak signifikan (Tabel 2). 


\section{Aktivitas kunjungan dan pollen load}

Aktivitas kunjungan tiga spesies lebah yang diamati bervariasi. Lebah $X$. confusa mengunjungi paling banyak bunga $(33,80 \pm 4,77$ bunga/menit), diikuti $A$. cyrtandrae (27,08 $\pm 2,29$ bunga/menit), dan C. cognata (2,24 $\pm 1,15$ bunga/menit). Lama kunjungan pada satu bunga paling lama adalah $C$. cognata (26,9 $\pm 14,63$ detik), diikuti $A$. cyrtandrae $(2,27 \pm 0,22$ detik) dan $X$. confusa $(1,81 \pm 0,85$ detik). Kunjungan lebah pada satu tanaman paling lama adalah $C$. cognata $(106,57 \pm 55,49$ detik $)$, diikuti $X$. confusa $(84,41 \pm 22,94$ detik) dan $A$. cyrtandrae (12,96 $\pm 2,60$ detik) (Tabel 3). Analisis pollen load menunjukkan $X$. confusa membawa polen terbanyak (13.375 polen), diikuti $A$. cyrtandrae (7.625 polen), dan C. cognata (3.325 polen) (Gambar 3).

\section{Keefektifan penyerbukan lebah pada tanaman tomat}

Lebah penyerbuk berperan dalam meningkatkan produksi buah tomat. Hal ini ditunjukkan oleh tanaman tomat yang terbuka yang menghasilkan panjang buah $(5,36 \pm 0,45 \mathrm{~cm})$, diameter buah $(4,96 \pm 0,41 \mathrm{~cm})$, bobotbuah $(87,57 \pm 10,43 \mathrm{~g})$, jumlah biji (118,9 $\pm 23,59$ biji/buah), dan bobot

Tabel 1. Jumlah spesies dan individu lebah penyerbuk pada bunga tomat

\begin{tabular}{|c|c|c|c|c|c|}
\hline \multirow{2}{*}{ Spesies } & \multicolumn{4}{|c|}{ Jumlah individu } & \multirow{2}{*}{ Persentase (\%) } \\
\hline & Pagi & Siang & Sore & Total & \\
\hline \multicolumn{6}{|l|}{ Megachilidae } \\
\hline Megachile conjuncta & 0 & 5 & 0 & 5 & 0,47 \\
\hline M. fulfifrons & 4 & 9 & 10 & 23 & 2,19 \\
\hline M. unbripennis & 5 & 10 & 26 & 41 & 3,90 \\
\hline \multicolumn{6}{|l|}{ Apidae } \\
\hline Xylocopa confusa & 239 & 169 & 49 & 457 & 43,56 \\
\hline$X$. latipes & 5 & 0 & 0 & 5 & 0,47 \\
\hline X. caerulea & 4 & 0 & 0 & 4 & 0,38 \\
\hline Ceratina cognate & 32 & 20 & 80 & 132 & 12,58 \\
\hline Nomia quadridentata & 27 & 29 & 67 & 123 & 11,72 \\
\hline Amegilla cyrtandrae & 106 & 73 & 48 & 227 & 21,64 \\
\hline A.burneensis & 3 & 2 & 7 & 12 & 1,14 \\
\hline Apis cerana & 4 & 7 & 9 & 20 & 1,90 \\
\hline Jumlah individu & 429 & 324 & 296 & 1049 & 100 \\
\hline Jumlah spesies & 10 & 9 & 8 & 27 & \\
\hline Rata-rata individu/hari & 40,89 & 30,88 & 28,21 & 41,96 & \\
\hline Indeks Shanon (H') & 1,821 & 1,448 & 1,266 & 1,59 & \\
\hline Indeks kemerataan (E) & 0,549 & 0,659 & 0,868 & 0,24 & \\
\hline
\end{tabular}

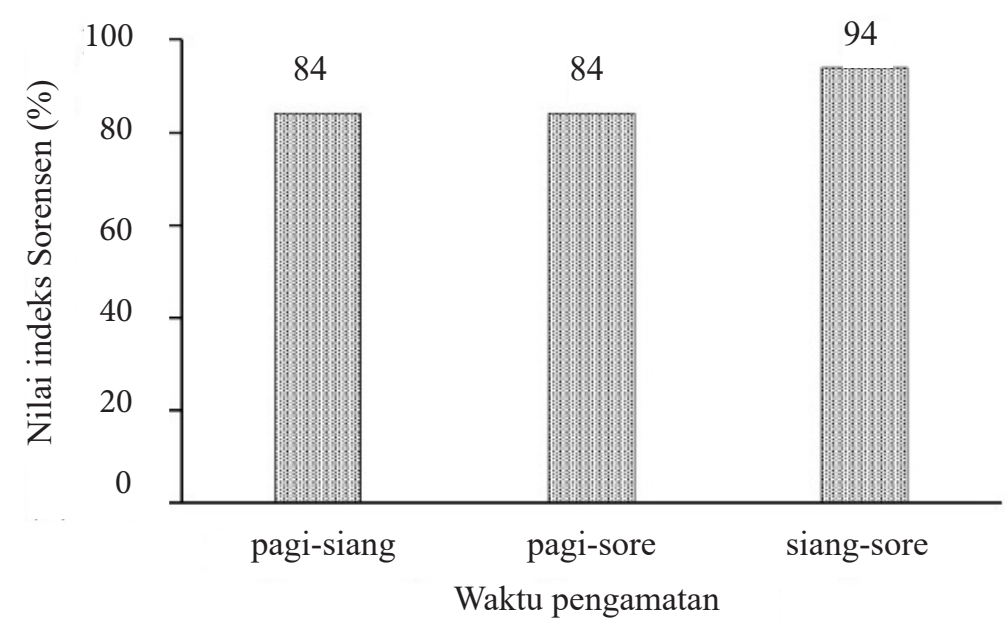

Gambar 1. Kesamaan spesies lebah penyerbuk tanaman tomat antar waktu pengamatan. 


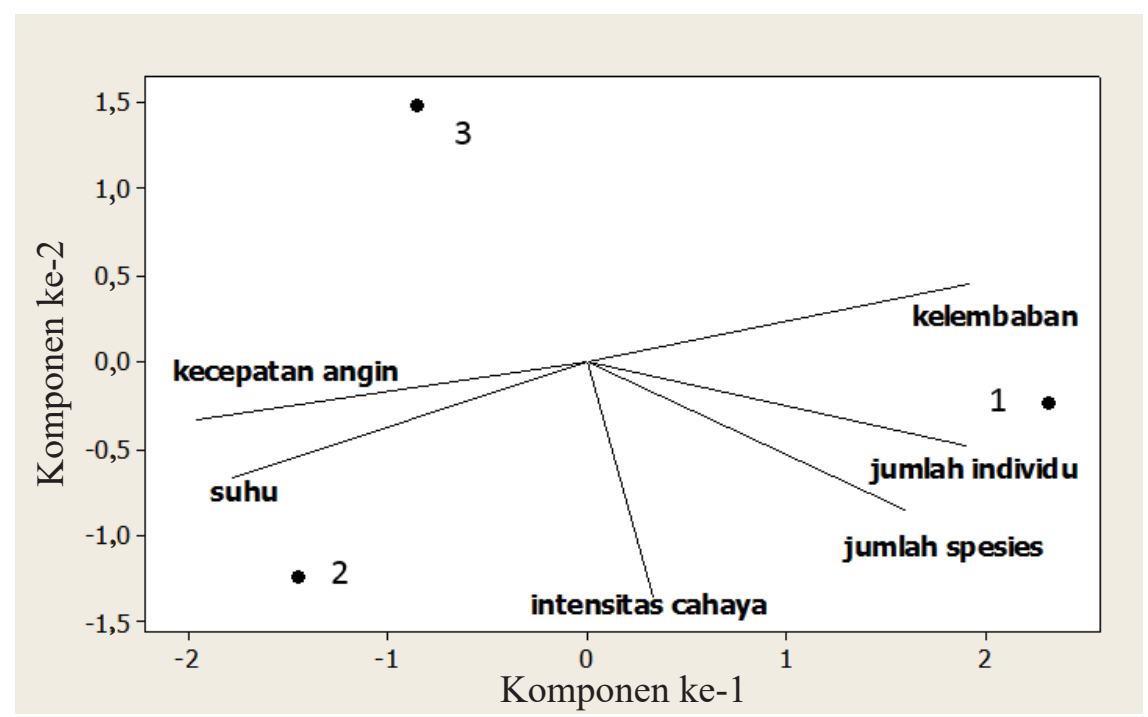

Gambar 2. Hasil analisis PCA tentang korelasi jumlah individu dan spesies lebah penyerbuk pertanaman tomat dengan parameter lingkungan.

Tabel 2. Korelasi Pearson antara jumlah spesies dan jumlah individu lebah penyerbuk dengan parameter lingkungan

\begin{tabular}{lcccc}
\hline \multirow{2}{*}{ Parameter lingkungan } & \multicolumn{2}{c}{ Nilai korelasi (r) } & \multicolumn{2}{c}{$p$-value } \\
\cline { 2 - 5 } & Jumlah spesies & Jumlah individu & Jumlah spesies & Jumlah individu \\
\hline Suhu udara & $-0,38$ & 0,65 & 0,74 & 0,54 \\
Kelembaban & $-0,53$ & $-0,76$ & 0,64 & 0,44 \\
Intensitas cahaya & 0,74 & 0,49 & 0,46 & 0,66 \\
Kecepatan angin & $-0,6$ & $-0,82$ & 0,58 & 0,38 \\
\hline
\end{tabular}

Tabel 3. Aktivitas kunjungan tiga spesies lebah penyerbuk pada tanaman tomat

\begin{tabular}{lcccc}
\hline Spesies & $\mathrm{n}$ & $\begin{array}{c}\text { Jumlah bunga } \\
\text { yang dikunjungi/ } \\
\text { menit* }\end{array}$ & $\begin{array}{c}\text { Lama kunjungan/ } \\
\text { bunga (detik)* }\end{array}$ & $\begin{array}{c}\text { Lama kunjungan/ } \\
\text { tanaman (detik)* }\end{array}$ \\
\hline Xylocopa confusa & 225 & $33,80^{\mathrm{a}}$ & $1,81^{\mathrm{b}}$ & $83,41^{\mathrm{b}}$ \\
Amegilla cyrtandrae & 175 & $27,08^{\mathrm{c}}$ & $2,27^{\mathrm{b}}$ & $12,96^{\mathrm{a}}$ \\
Ceratina cognata & 91 & $2,24^{\mathrm{b}}$ & $26,9^{\mathrm{a}}$ & $106,57^{\mathrm{b}}$ \\
\hline
\end{tabular}

*Huruf yang sama pada kolom yang sama menunjukkan tidak berbeda nyata pada ANOVA level 95\% dilanjutkan uji Tukey. $\mathrm{n}$ : total pengamatan.

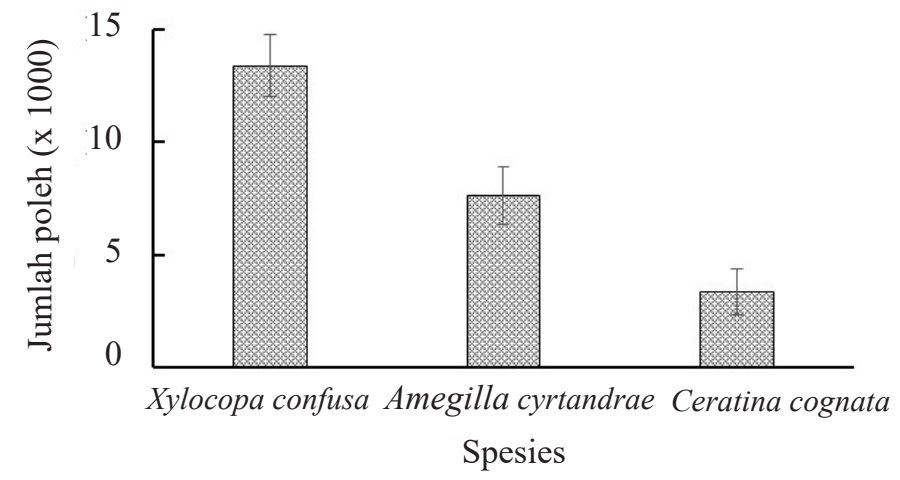

Gambar 3. Jumlah polen yang menempel pada tubuh tiga spesies lebah penyerbuk. 
biji $(0,41 \pm 0,11 \mathrm{~g} /$ buah $)$ lebih tinggi dibandingkan dengan tanaman tomat yang dikurung, yaitu panjang buah $(3,75 \pm 0,53 \mathrm{~cm})$, diameter buah $(2,95 \pm 0,24 \mathrm{~cm})$, bobot buah $(72,66 \pm 5,21 \mathrm{~g})$, jumlah biji/buah $(41,10 \pm 13,77 \mathrm{biji})$, dan bobot biji/buah $(0,09 \pm 0,03 \mathrm{~g})$. Tanaman tomat yang terbuka menghasilkan panjang, diameter, bobot buah, jumlah biji/buah, dan bobot biji/buah yang lebih tinggi dibandingkan dengan tanaman tomat yang dikurung dengan nilai signifikan $\mathrm{p}=0,000$ (Tabel 4). Pada tanaman tomat yang terbuka, terjadi peningkatan $8,92 \%$ jumlah bunga menjadi buah, $43 \%$ panjang buah, $68 \%$ diameter buah, $20 \%$ bobot buah, $189 \%$ jumlah biji/buah, dan 355\% bobot biji/buah, dibandingkan dengan pertanaman yang dikurung.

\section{PEMBAHASAN}

Berdasarkan pengamatan, X. confusa, $C$. cognate, dan $A$. cyrtandrae mengunjungi bunga tomat secara intensif. Jumlah individu $X$. confusa dan $A$. cyrtandrae yang mengunjungi tanaman tomat tinggi pada pagi hari dan menurun pada sore hari. Kunjungan $C$. cognata tinggi di sore hari pada bunga tomat. Hal ini menunjukkan bahwa $C$. cognata aktif sepanjang hari. Lebah Ceratina memaksimalkan pencarian pakan untuk mendapatkan polen dan nektar dari berbagai jenis tanaman (Raju et al. 2001). Lebah M. conjuncta dan M. unbripennis memiliki frekuensi kunjungan yang rendah pada tanaman tomat (5 dan 41 individu). Lebah $X$. caerulea dan $X$. latipes hanya mengunjungi bunga tomat pada pagi hari selama lima hari selama pengamatan. Pada penelitian ini, semua jenis penyerbuk tanaman tomat adalah lebah. Namun, jenis penyerbuk pada pertanaman tomat di Cisarua, Bogor, sedikit berbeda dengan Widhiono \& Sudiana (2015) yang melaporkan terdapat sepuluh jenis penyerbuk yang mengunjungi pertanaman tomat di lereng Utara Gunung Slamet, Jawa Tengah, dan hanya enam diantaranya yang termasuk kelompok lebah (Amegilla cingulata (Fabricius), Trigona, Lasioglossum malachurum (Kirby), Lasioglossum leucozonium (Schrank), X. latipes, Hylaeus modestus Say). Hal ini berkaitan dengan jumlah atau ketersediaan bunga sebagai sumber pakan karena ketertarikan serangga mengunjungi bunga, salah satunya adalah jumlah dan jenis tanamannya (Wratten et al. 2012). Dalam melakukan pencarian pakan, lebah menunjukkan flower constancy pada pertanaman sebagai sumber pakan yang terdekat dari sarangnya (Sadeh et al. 2007; Bernardino \& Gaglianone 2008; Rianti et al. 2010). Aktivitas pencarian pakan pada lebah dipengaruhi oleh ketersediaan pakan dan kondisi lingkungan (Sadeh et al. 2007). Aktivitas terbang lebah berkurang pada suhu rendah dan kelembaban tinggi karena memerlukan energi yang besar untuk memanaskan suhu toraks sampai $35^{\circ} \mathrm{C}$ (Yao et al. 2006).

Aktivitas kunjungan dan kesesuaian karakter tubuh lebah penyerbuk dengan bunga berpengaruh terhadap keberhasilan penyerbukan (Mensah \& Kudom 2011; Depra et al. 2014). Lama kunjungan lebah pada bunga dipengaruhi oleh perilaku mengambil polen. Lebah $X$. confusa dan $A$. cyrtandrae mengambil polen dengan cara menggetarkan anter yang menyebabkan jumlah polen

Tabel 4. Perbandingan hasil penyerbukan pada tanaman terbuka dan dikurung

\begin{tabular}{|c|c|c|c|c|}
\hline \multirow{2}{*}{ Komponen } & \multirow{2}{*}{$\mathrm{n}$} & \multicolumn{2}{|c|}{ Pertanaman* } & \multirow{2}{*}{ Peningkatan $(\%)$} \\
\hline & & Dikurung kain kasa & Terbuka & \\
\hline Panjang buah (cm) & 20 & $3,75^{b} \pm 0,53$ & $5,36^{\mathrm{a}} \pm 0,45$ & 43 \\
\hline Diameter buah (cm) & 20 & $2,95^{\mathrm{b}} \pm 0,24$ & $4,96^{\mathrm{a}} \pm 0,41$ & 68 \\
\hline Berat buah (g) & 20 & $72,66^{b} \pm 5,21$ & $87,57^{\mathrm{a}} \pm 10,43$ & 20 \\
\hline Jumlah biji/buah & 20 & $41,10^{b} \pm 13,77$ & $118,9^{\mathrm{a}} \pm 23,59$ & 189 \\
\hline Bobot biji/buah (g) & 20 & $0,09^{b} \pm 0,03$ & $0,41^{\mathrm{a}} \pm 0,11$ & 355 \\
\hline Bobot menjadi buah (\%) & 20 & 90,81 & 98,91 & 8,92 \\
\hline Vitamin C (mg/100 g) & 1 & 1,06 & 0,40 & \\
\hline Karbohidrat (\%) & 1 & 3,85 & 4,10 & \\
\hline Protein $(\%)$ & 1 & 45,70 & 38,10 & \\
\hline
\end{tabular}

*Huruf berbeda pada baris yang sama menunjukkan berbeda nyata dengan uji T level 95\%. 
yang jatuh lebih banyak dalam waktu singkat (Sadeh et al. 2007), sedangkan C. cognata mengambil polen dengan cara memasukkan probosisnya ke dalam anter. Beberapa lebah penyerbuk dilaporkan menggetarkan anter untuk mengambil polen, seperti A. chlorocyanea pada bunga tomat di Australia (Hogendoorn et al. 2007), Xylocopa ordinaria Smith pada bunga Solanum curvispinum di Brazil (Bernardino \& Gaglianone 2008), Hylaeus sp. pada bunga tomat di Bogor (Fajarwati et al. 2009). Rendahnya aktivitias kunjungan Ceratina juga dilaporkan pada bunga caisin, yaitu 5,5 bunga/menit (Atmowidi 2008). Tingginya kunjungan Xylocopa (20,86 bunga/menit) juga dilaporkan pada tanaman Jatropha curcas (Rianti et al. 2010) dan X. olivacea pada bunga Phaseolus vulgaris (28 bunga/menit dan 20 bunga/menit) (Kingha et al. 2012). Kemampuan $X$. confusa mengunjungi banyak bunga dalam waktu yang singkat karena ukuran tubuhnya besar sehingga memungkinkan polen yang terkumpul lebih banyak (Sadeh et al. 2007). Dalam pengamatan, lebah $A$. cerana tidak intensif mengunjungi tomat. Hal ini bisa disebabkan karena A. cerana lebih memilih tanaman lain sebagai sumber pakannya. Faktor lain adalah sedikitnya nektar yang dihasilkan oleh bunga tomat (Delaplane \& Mayer 2000) sehingga A. cerana cenderung mengunjungi tanaman lain yang menghasilkan banyak nektar. Mensah \& Kudom (2011) melaporkan bahwa lebah Apis intensif mengunjungi bunga Luffa aegyptiaca pada pagi hari untuk mendapatkan nektar.

Lebah penyerbuk yang intensif mengunjungi bunga dapat mempercepat proses penyerbukan dan fertilisasi (Husby et al. 2015). Pada pertanaman tomat yang dikurung, 9,19\% bunga tidak membentuk buah, sedangkan pada tanaman terbuka, hanya $1,09 \%$ bunga yang tidak berhasil membentuk buah. Pada pertanaman dalam kurungan, terjadi penurunan viabilitas polen karena tidak terserbuki selama beberapa jam atau beberapa hari (Widiastuti \& Palupi 2008; Kahriman et al. 2015). Beberapa penelitian melaporkan, terjadi peningkatan jumlah, ukuran buah dan jumlah biji tanaman tomat hasil penyerbukan oleh lebah $M$. quadrifasciata dan A. mellifera (Santos et al. 2009), E. analis di Brazil (Neto et al. 2013; Depra et al. 2014), A. holmesi dan A. chlorocyanea di Australia (Bell et al. 2006; Hogendoorn et al. 2007). Selain peningkatan ukuran buah, penyerbukan oleh lebah juga menghasilkan buah yang lebih padat (Neto et al. (2013). Cauich et al. (2004) di Meksiko, juga melaporkan terjadi peningkatan jumlah buah, bobot buah, jumlah biji/buah, pada buah tomat yang diserbuki oleh Nannotrigona perilampoides (Cresson), dibandingkan dengan buah tomat tanpa bantuan lebah dan vibrator mekanik. Eilers et al. (2011) juga melaporkan bahwa terdapat jumlah nutrisi (vitamin A, C, E, lipid, protein dan mineral) yang tinggi pada buah hasil penyerbukan serangga. Namun hasil penelitian di Cisarua menunjukkan nilai yang berbeda, yaitu kandungan vitamin $\mathrm{C}$ dan protein yang lebih rendah pada buah hasil penyerbukan lebah. Hal ini terjadi karena jumlah sampel dan komponen nutrisi yang diukur pada penelitian ini sangat sedikit, yaitu karbohidrat, protein dan vitamin $\mathrm{C}$ sehingga memungkinkan belum mewakili seluruh kandungan nutrisi pada buah tomat, berbeda dengan penelitian Eilers et al. (2011) yang mengukur komponen nutrisi dalam jumlah yang banyak.

\section{KESIMPULAN}

Pertanaman tomat di lahan pertanian organik Cisarua dikunjungi oleh 11 spesies lebah, Tiga spesies lebah, yaitu X. confusa, A. cyrtandare dan C. cognata ditemukan dominan mengunjungi pertanaman tomat setiap hari selama pengamatan. Penyerbukan dengan bantuan lebah tersebut meningkatkan ukuran panjang buah, diameter buah, bobot buah, jumlah biji/buah, dan bobot biji/buah tanaman tomat.

\section{UCAPAN TERIMA KASIH}

Terima kasih kepada Ditjen Dikti yang telah memberikan Beasiswa Pendidikan Pascasarjana Dalam Negeri dan mendanai penelitian ini.

\section{DAFTAR PUSTAKA}

Atmowidi T. 2008. Keanekaragaman dan Perilaku Kunjungan Serangga Penyerbuk serta Pengaruhnya dalam Pembentukan Biji Tanaman Caisin (Brassica rapa L: Brassicaceae). Disertasi. Bogor: Institut Pertanian Bogor. 
Bell MC, Spooner-Hart RN, Haigh AM. 2006. Pollination of greenhouse tomatoes by the australian bluebanded bee Amegilla (Zonamegilla) homesi (Hymenoptera: Apidae). Journal of Economic Entomology 99:437-442. doi: http: //dx.doi.org/10.1603/0022-0493-99.2.437.

Bernardino AS, Gaglianone MC. 2008. Nest distribution and nesting habits of Xylocopa ordinaria Smith (Hymenoptera, Apidae) in a restinga area in The Northern Rio de Janeiro State, Brazil. Revista Brasileira de Entomologia. Journal of Economic Entomology 52:434-440. doi: http: //dx.doi.org/10.1590/S0085-56262008000300017.

Cauich O, Quezada-Euan JJG, Macias-Macias JO, Reyes-Oregel V, Median-Veralta S, Parra-Tabla V. 2004. Behavior and pollination efficiency of Nannotrigona perilampoides (Hymenoptera: Meliponini) on greenhouse tomatoes (Lycopersicon esculentum) in subtropical Mexico. Journal of Economic Entomology 97:475-481. doi: http://dx.doi.org/10.1603/0022-0493-97.2.475.

Dafni A. 1992. Pollination Ecology a Practical Approach. New York: Oxford Univ Pr.

Delaplane KS, Mayer DE. 2000. Crop Pollination by Bees. New York: CABI Publishing. doi: http:// dx.doi.org/10.1079/9780851994482.0000.

Depra MS, Delaqua GCG, Freitas L, Gaglianone MC. 2014. Pollination deficit in open field tomato crops (Solanum lycopersicum L., Solanaceae) in Rio de Janeiro State, Southeast Brazil. Journal of Pollination Ecology 12:1-8.

Duwi P. 2010. Paham Analisis Statistika dengan SPSS. Yogyakarta: Mediakom.

Eilers EJ, Kremen C, Greenleaf SS, Garber AK, Klein AM. 2011. Contribution of pollinator-mediated crops to nutrients in the human food supply. PlosOne 6:1-6. doi: http://dx.doi.org/10.1371/ journal.pone.0021363.

Fajarwati MR, Atmowidi T, Dorly. 2009. Keanekaragaman serangga pada bunga tomat (Lycopersicon esculentum Mill.) di lahan pertanian organik. Jurnal Entomologi Indonesia 6:77-85.

Hogendoorn K, Coventry S, Keller MA. 2007. Foraging behaviour of a blue banded, Amegilla chlorocyanea in greenhouse: implications for use a tomato pollinators. Apidologie 38:86-92. doi: http://dx.doi.org/10.1051/apido:2006060.

Hurd PD, Moure JS. 1963. A Classification of the Large Carpenter Bees (Xylocopini) (Hymenoptera: Apoidea). Berkeley and Los Angeles: University of California Pr.

Husby JF, LeRoy CJ, Fimbel C. 2015. Pollinators may not limit native seed set at puget lowland prairie restoration nurseries. Journal of Pollination Ecology 15:30-37.

Kahriman F, Egesel CO, Aydin T, Subasi S. 2015. The role of artificial pollination and pollen effect on ear development and kernel structure of different maize gentypes. Journal of Pollination Ecology 15:6-14.

Kingha BMT, Fohouo FNT, Ngakou A, Bruckner D. 2012. Foraging and pollination activities of Xylocopa olivacea (Hymenoptera, Apidae) on Phaseolus vulgaris (Fabaceae) flowers at Dang (Ngaoundere-Cameroon). Journal of Agricultural Extension and Rural Development 4:330-339.

Kunjwal N, Kumar Y, Khan MS. 2014. Flower visiting insect pollinators of brown mustard, Brassica juncea (L.) czern and coss and their foraging behaviour under caged and open pollination. African Journal of Agricultural Research 9:1278-1286.

Magurran AE, McGill BJ. 2011. Biological Diversity. New York: Oxford Univ. Pr.

Martin P, Bateson P. 1986. Measuring Behavior: an Intoductory Guide. Cambridge: Cambridge Univ.

Mburu J, Hein LG, Gemmill B, Collette L. 2006. Economic Valuation of Pollination Services. Italia: Food and Agriculture Organization of the United Nations Agriculture Department, Seed and Plant Genetic Resources Division (AGPS).

Mensah, Kudom. 2011. Foraging dynamics and pollination efficiency of Apis mellifera dan Xylocopa olivacea on Luffa aegyptiaca Mill (Cucurbitaceae) in Southern Ghana. Journal of Pollination Ecology 4:34-38.

Michener CD. 2007. The Bees of the World. Baltimore. Baltimore: The John Hopkins University Press.

Morse RA, Calderone NW. 2000. The Value of Honey Bees as Pollinators of U.S. Crops in 2000. New York: Cornell University.

Neto CMS, Lima FG, Goncalves BB, Bergamini LL, Bergamini BAR, Elias MAS, Franceshinelli EV. 2013. Native bees pollinate tomato flowers and increase fruit production. Journal of Pollination Ecology 11:41-45.

Raju AJS, Rao SP, Sri SV. 2001. Foraging ecology of Ceratina and pollination in some Indian plants. Indian Bee Journal 64:35-44.

Rianti P, Suryobroto B, Atmowidi T. 2010. Diversity and efectiveness of insect pollinators of Jatropha curcas L. (Euphorbiaceae). HAYATI Journal of Biosciences 17:38-42.http://dx.doi.org/10.4308/ hjb.17.1.38.

SadehA, ShmidaA, KeasarT. 2007. The carpenter bee Xylocopa pubescens as an agricultural pollinator 
in greenhouse. Apidologie 38:508-517. doi: http://dx.doi.org/10.1051/apido:2007036.

Santos SABd, Roselino AC, Hrncir M, Bego LR. 2009. Pollination of tomatoes by stingless bee Melipona quadrifasciata and the honey bee Apis mellifera (Hymenoptera, Apidae). Genetics and Molecular Research 8:751-757. doi: http://dx.doi.org/10.4238/vol8-2kerr015.

Silva PN, Hnrcir M, Shipp L, Fonseca VLI, Kevan PG. 2013. The behaviour of Bombus impatiens (Apidae, Bombini) on tomato (Lycopersicon esculentum Mill. Solanaceae) flowers: pollination and reward perception. Journal of Pollination Ecology 11:33-40.

Triplehorn CA, Johnson NF. 2005. Borror and Delong's Introduction to the Study of Insect. Belmont: Brooks/Cole Thomson Learning, Inc.

Widhiono I, Sudiana E. 2015. Serangga penyerbuk dan hubungannya dengan warna bunga pada tanaman pertanian di Lereng Utara Gunung Slamet, Jawa Tengah. Biospecies 8:43-50.
Widiastuti A, Palupi ER. 2008. Viabilitas serbuk sari dan pengaruhnya terhadap keberhasilan pembentukan buah kelapa sawit (Elaeis guineensis Jacq.). Biodiversitas 9:35-38. doi: http://dx.doi. org/10.13057/biodiv/d090109.

Wratten DS, Gillespie M, Decortye A, Mader E, Desneux N. 2012. Pollinator habitat enhancement: Benefits to other ecosystem services. Agriculture, Ecosystems, and Environment 159:112-122. doi: http://dx.doi.org/10.1016/j.agee.2012.06.020.

Yao YF, Bera S, Wang YF, Li Cs. 2006. Nectar and pollen sources for honeybee (Apis cerana cerana Fabr.) in Qinglan Mangrove Area, Hainan Island, China. Journal of Integrative Plant Biology 48:1266-1273. doi: http://dx.doi.org/10.1111/j. 1744-7909.2006.00353.x. 